\title{
Attitudes and Preferences of Consumers Towards Functional Foods Enriched with Omega-3 Fatty Acids
}

\author{
Birsen Demirel $^{1}$, Alev Yüksel-Bilsel ${ }^{2}$, Neşe Şahin-Yeşilçubuk ${ }^{3 *}$ \\ ${ }^{1}$ Istanbul Bilgi University, Faculty of Health Science, Departmant of Nutrition and Dietetics, İstanbul, Turkey, (ORCID: 0000-0003-3897-1446), \\ birsen.demirel@bilgi.edu.tr \\ ${ }^{2}$ Istanbul Galata University, Faculty of Arts and Social Sciences, Departmant of Gastronomy and Culinary Arts, İstanbul, Turkey, (ORCID: 0000-0002-3795-9077), \\ alev.bilsel@galata.edu.tr \\ 3* Istanbul Technical University, Faculty of X Chemical and Metallurgical, Departmant of Food Engineering, İstanbul, Turkey, (ORCID: 0000-0002-4179-1932), \\ sahinnes@itu.edu.tr
}

(First received 21 February 2021 and in final form 8 July 2021)

(DOI: $10.31590 /$ ejosat.884022)

ATIF/REFERENCE: Demirel, B., Yüksel-Bilsel, A. \& Şahin-Yeşilçubuk, N. (2021). Attitudes and Preferences of Consumers Towards Functional Foods Enriched with Omega-3 Fatty Acids. European Journal of Science and Technology, (25), 485-492.

\begin{abstract}
In recent years, increasing attention has focused on foods enriched with omega-3 fatty acids due to their positive effects on health.. Natural omega-3 fatty acid sources include aquaculture and plants such as walnut, flaxseed, and purslane. In view of the inadequate intake of omega-3 fatty acids in modern diets, several enriched functional foods have been developed on a large scale to improve nutrition. Several types of functional products have been progressively manufactured following the advent of novel food technologies. In the current study, consumer attitudes, knowledge and preferences of functional foods enriched with omega-3 were assessed in a survey including 819 participants in Istanbul, Turkey. The survey findings revealed that $72 \%$ of the participants consumed omega-3 fatty acids from natural sources, $17 \%$ used fish oil capsules, and only $11 \%$ preferred foods enriched with omega- 3 fatty acids.
\end{abstract}

Keywords: Omega-3 fatty acids, Functional foods, Consumer, Attitude, Perception.

\section{Tüketicilerin Omega-3 Yă̆ Asitleri ile Zenginleștirilmiş Fonksiyonel Gıdalara Yönelik Tutum ve Tercihleri}

Öz

Son yıllarda sağlık üzerindeki olumlu etkileri nedeniyle omega-3 yağ asitleri ile zenginleştirilmiş gıdalara ilgi artmaktadır. Doğal omega-3 yağ asidi kaynakları arasında su ürünleri ile ceviz, keten tohumu ve semizotu gibi bitkiler bulunur. Modern diyetlerde omega-3 yağ asitleri yeterince alınmadığından ötürü beslenmeyi iyileştirmek için çeşitli zenginleştirilmiş fonksiyonel gıdalar büyük ölçekte geliştirilmiştir. Yeni gıda teknolojilerinin ortaya çıkmasının ardından aşamalı olarak çeşitli fonksiyonel ürünler üretilmiştir. Bu çalışmada, omega-3 ile zenginleştirilmiş fonksiyonel gıdalara yönelik tüketici tutumu, bilgisi ve tercihleri İstanbul'daki 819 tüketicinin katıldığ yağ asitleri tükettiğini, \% 17'sinin balık yağı kapsülleri kullandığını ve sadece \% 11'inin omega-3 yağ asitleri ile zenginleştirilmiş yiyecekleri tercih ettiği bulunmuştur.

Anahtar Kelimeler: Omega-3 yağ asitleri, Fonksiyonel gıdalar, Tüketici, Tutum, Alg1

\footnotetext{
*Corresponding Author: sahinnes@itu.edu.tr
} 


\section{Introduction}

Lipids perform important functions in the body and are necessary in the human diet (Jacobsen, 2010). Supportive but not conclusive research shows that, omega- 3 fatty acids may have numerous benefits such as reducing the risk of cancer, heart disease, inflammation, arthritis, diabetes and high cholesterol (Mazza et al., 2007; Saini \& Keum, 2018). Eicosapentaenoic acid (EPA) and docosahexaenoic acid (DHA) are omega-3 fatty acids associated with prevention of Alzheimer's disease, fetal development and cardiovascular activities (Swanson et al., 2012).

Oily fish contain a high amount of the long-chain omega-3 fatty acids EPA and DHA (Williams \& Burdge, 2006). Scientific authorities recommend consumption of fish twice a week to benefit from omega-3 fatty acids. Omega- 3 fatty acids are also ingested in the form of supplements. However, omega- 3 fatty acids are not adequately consumed by the majority of the population (Lane \& Derbyshire, 2018). According to the Turkey Nutrition and Health Survey report (TBSA, 2019), the intake of EPA+DHA is between 0.2 and 0.3 grams $( \pm 0.47-0.89 \mathrm{~g})$ in men and 0.2 grams $( \pm 0.39-0.64 \mathrm{~g})$ in women in all age groups which is less than recommended values. Omega-3 enriched functional foods have been a significant recent trend. These novel functional food products are launched by the way traditional food markets. At present, consumers have increased dietary choices, such as egg, milk and bread products enriched with omega-3 fatty acids (Cox et al., 2008; Jacobsen, 2010).

A combination of social, psychological, and economic factors exerts important effects on functional food intake (Patch et al., 2005). Additionally, consumer acceptance plays a crucial role in the development and marketing of functional foods (Siró et al., 2008). In Turkey, limited consumer studies regarding omega-3 enriched foods have been conducted. Accordingly, we investigated omega-3 fatty acid consumption patterns, consumer attitudes, and preferences of Turkish consumers towards functional foods enriched with omega-3 fatty acids in this study. To this end, a consumer survey was performed and the results obtained from 819 participants were analyzed.

\section{Material and Method}

\subsection{Data Collection and Analysis}

An internet survey was conducted from December 2, 2015, to January 1,2016 , incorporating 819 participants. In accordance with the purpose of the survey, the respondents were selected from young and middle-aged adults who are responsible for grocery shopping and are living in Istanbul, the most densely populated city of Turkey. The "VETI" ("Data Collection and Statistics System") program developed by Istanbul Technical University was used to prepare and distribute the questionnaire and evaluate the survey results. SPSS (Statistical Package for Social Sciences, Version 22) was used for statistical analysis of the responses. Non-parametric tests, such as Mann-Whitney U and Kruskal-Wallis, were conducted to determine the differences between independent factors (gender, education, income level), since the data were not normally distributed according to the Shapiro-Wilk test. Additionally, Tamhane's T2 post-hoc test was used to evaluate differences within the groups. Moreover, Descriptive statistics were used to describe continuous variables (mean, standard deviation, minimum, median, maximum). frequency and percentage values were calculated for the descriptive statistics of categorical variables for consumption frequency. Chi-Square (or Fisher Exact test, where appropriate) was used to examine the relationship between categorical variables. Statistical significance level was determined as 0.05. Analysis were performed using MedCalc Statistical Software version 12.7.7 (MedCalc Software bvba, Ostend, Belgium; 2013).

\subsection{Questionnaire Design}

To assess consumer attitudes, perception and knowledge with regard to functional foods enriched with omega-3, dichotomous questions (yes/no), multiple choice questions and the five-point Likert-type scale were used. The survey comprised three main sections including a total of 18 questions. The first seven questions involved demographic information on participants, the next five questions assessed omega-3 consumption, and the final six questions evaluated the functional foods enriched with omega-3 consumed in Turkey.

\section{Results and Discussion}

\subsection{Results}

\subsubsection{Sample Demographics}

The socio-demographic profiles of the respondents are presented in Table 1. According to the responses, female participants accounted for more than half of the study group. Overall, 53\% participants were female and $47 \%$ were male.

Table 1. Socio-demographic characteristics of the sample $(n=$ 819)

\begin{tabular}{|c|c|c|}
\hline & $(n)$ & $(\%)$ \\
\hline \multicolumn{3}{|l|}{ Gender } \\
\hline Female & 435 & 53 \\
\hline Male & 384 & 47 \\
\hline \multicolumn{3}{|l|}{ Age (years) } \\
\hline $18-30$ & 500 & 61 \\
\hline $31-40$ & 156 & 19 \\
\hline $41-50$ & 106 & 13 \\
\hline$>50$ & 57 & 7 \\
\hline \multicolumn{3}{|l|}{ Marital status } \\
\hline Single & 541 & 66 \\
\hline Married & 278 & 34 \\
\hline \multicolumn{3}{|l|}{ Presence of children } \\
\hline Yes & 238 & 29 \\
\hline No & 581 & 71 \\
\hline \multicolumn{3}{|l|}{ Education } \\
\hline Primary School & 8 & 1 \\
\hline High School & 229 & 28 \\
\hline Bachelor's Degree & 459 & 56 \\
\hline Higher Degree & 123 & 15 \\
\hline \multicolumn{3}{|l|}{ Job status } \\
\hline Civil Servant & 360 & 44 \\
\hline Freelancer & 74 & 9 \\
\hline Retired & 25 & 3 \\
\hline Private Sector & 49 & 6 \\
\hline Student & 295 & 36 \\
\hline Other & 16 & 2 \\
\hline \multicolumn{3}{|l|}{ Income (per month) } \\
\hline$<1000$ TRY $(<345 \$)$ & 213 & 26 \\
\hline 1000-2000 TRY (345-690 \$) & 180 & 22 \\
\hline 2000-3000 TRY (690-1035\$) & 254 & 31 \\
\hline 3000-5000 TRY (1035-1725\$) & 115 & 14 \\
\hline$>5000$ TRY $(>1725 \$)$ & 57 & 7 \\
\hline
\end{tabular}


The age range of more than half of the participants was 1830 years. Specifically, $61 \%$ were $18-30$ years, $19 \%$ were $31-40$ years, $13 \%$ were $41-50$ years, and $7 \%$ were older than 50 years (Table 1).

Overall, 66\% respondents were single and $44 \%$ were married (Table 1). Additionally, 29\% consumers had children and $71 \%$ had no children. More than half the consumers had a bachelor's degree (56\% were university graduates), $15 \%$ had a master's or higher degree, $28 \%$ had graduated from high school, and $1 \%$ were educated to primary school level.

As presented in Table 1, 44\% participants worked in a public institution, $6 \%$ were in the private sector, $9 \%$ were freelance, $36 \%$ were students and $3 \%$ were retired. In terms of total monthly income, $26 \%$ participants earned less than 1000
TRY, 22\% earned 1000-2000 TRY, 31\% earned 2000-3000 TRY, $14 \%$ earned $3000-5000$ TRY and $7 \%$ earned over 5000 TRY.

\subsubsection{Consumer Knowledge and Awareness}

In the survey, participants were asked if they had any knowledge of omega-3 fatty acids and their main source of information. Only $2 \%$ of the participants had never encountered the term 'omega-3 fatty acids' before (Figure 1). Among the 819 respondents, $43 \%$ had obtained information from television, $22 \%$ from school, $12 \%$ from the internet, $7 \%$ from doctors, and $4 \%$ from newspapers. The remaining participants had received information from food engineers, dieticians or other sources, such as family members, friends, and books.

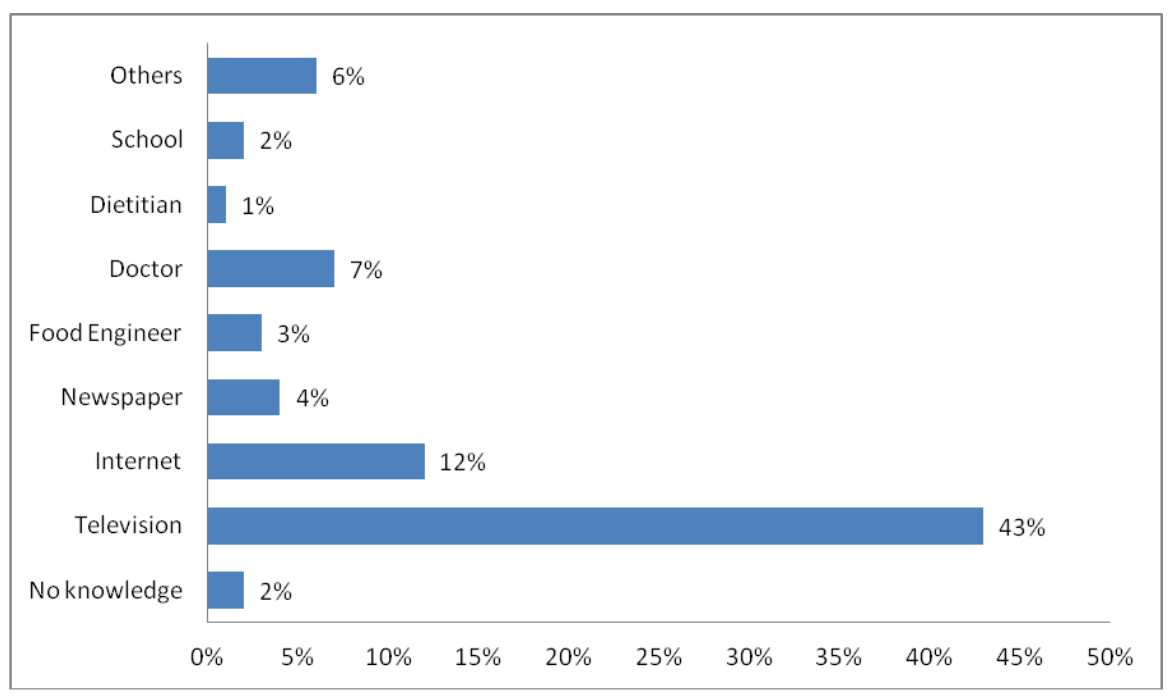

Figure 1. Distribution of participants according to information sources.

The following question focused on knowledge on the health benefits of omega-3 fatty acids (Figure 2). The most common response was decreasing heart attack risk (31\%). Overall, 24\% of the participants were aware of the health benefits of omega- 3 fatty acids on the immune system and $20 \%$ were familiar with health benefits during pregnancy and brain and eye development of infants. Furthermore, $13 \%$ participants were aware of the effect of omega-3 fatty acids on prevention of hypertension and $12 \%$ on their use in the treatment of depression and behavioral disorders.

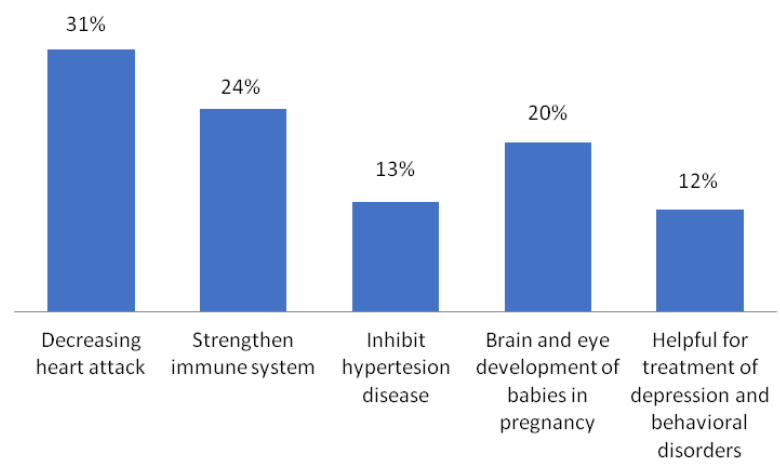

Figure 2. Distribution of participants according to knowledge on health benefits of omega-3 fatty acids.

Participants were required to select foods containing natural omega-3 fatty acids to assess their knowledge on natural sources. According to Figure 3, although all options in the survey were natural omega-3 sources, fish was the most wellknown source. Walnut was selected as another natural omega-3 fatty acid source according to $25 \%$ participants whereas $13 \%$ considered flaxseed a natural source. In addition, $8 \%$ of the respondents selected purslane, $6 \%$ selected canola oil, $7 \%$ selected soybean oil, and $3 \%$ identified krill oil as natural omega-3 fatty acid sources.

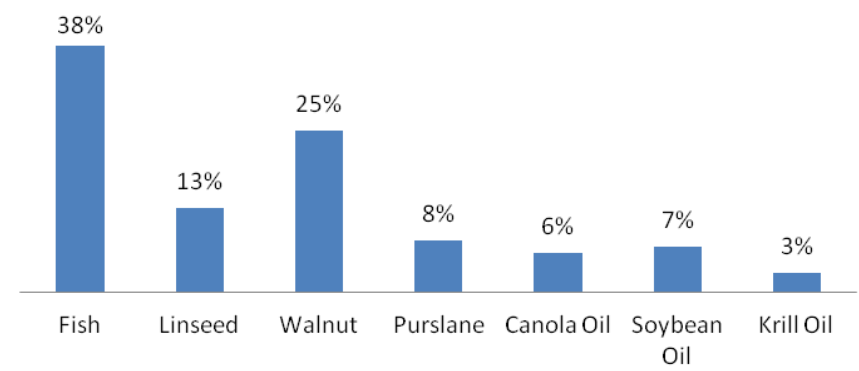

Figure 3. Distribution of participants according to knowledge on natural omega-3 fatty acid sources.

In another question of the survey, information on awareness of the presence of omega-3 fatty acid enriched foods in Turkey market was obtained. According to the data, more than half the participants $(57 \%)$ had never encountered omega-3 enriched foods whereas $43 \%$ knew about foods enriched with omega-3 fatty acids within the market. According to statistical data, no significant differences were observed between gender, marital status, age, education, and income level groups $(P>0.05)$. 
In subsequent question, participants were asked to select listed foods declared or labeled as containing omega-3 fatty acids in order to assess consumer knowledge on the presence of enriched foods. Margarine was the most popular response by $31 \%$ participants. Infant formulae and eggs were known foods enriched with omega- 3 fatty acids by only $19 \%$ participants and vegetable oil identified as an omega-3-rich food by $27 \%$ participants. A small proportion (3\%) of participants selected other options, such as fish cans, chocolates and bread.

\subsubsection{Consumer Knowledge and Awareness}

In the survey, a question aimed to obtain information on ways through which omega-3 fatty acids are consumed. The results showed that the vast majority of the participants obtained omega-3 fatty acids by consuming natural foods. Overall, $72 \%$ participants preferred natural foods containing omega-3 fatty acids, $17 \%$ preferred fish oil capsules, and $11 \%$ preferred foods enriched with omega-3 fatty acids.

In a question of the survey, the consumption frequency of specific foods containing omega-3 fatty acids was established. According to data collected from the responses, $33 \%$ participants consumed fish once a week (the highest frequency of consumption) while $11 \%$ participants consumed fish less than once a month (the lowest frequency of consumption).

The majority $(81 \%)$ of participants consumed flaxseed less than once a month whereas $42 \%$ consumed walnuts more than twice a week. In addition, purslane was consumed less than once a month by $42 \%$ respondents, whereas $91 \%$ participants consumed canola oil, $87 \%$ consumed soybean oil, and $95 \%$ consumed krill oil less than once a month.

Purchasing attitudes towards foods enriched with omega-3 fatty acids were determined in the survey. As shown in Figure 4, margarine $(33 \%)$ was the most popular response. Other foods purchased by participants were infant formula $(6 \%)$, vegetable oil $(27 \%)$, and eggs (25\%). Moreover, 9\% of the consumers selected other choices, such as fish cans, chocolates and none of them.

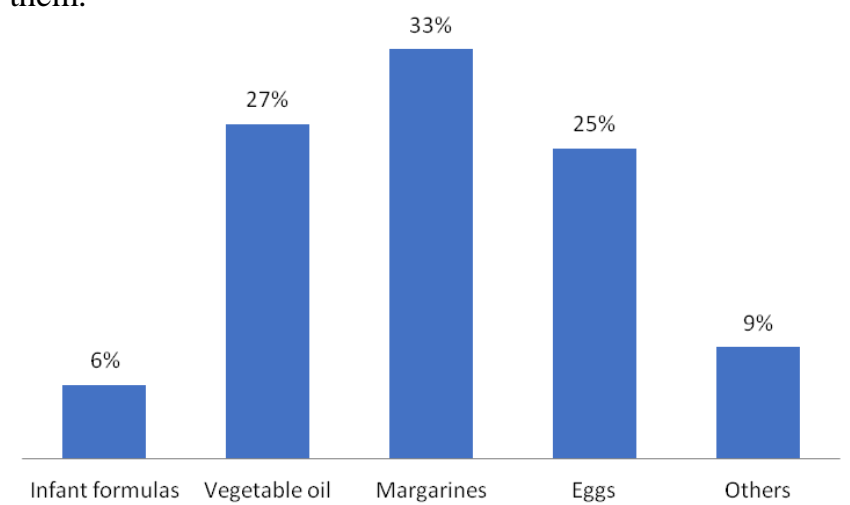

Figure 4. Distribution of participants according to purchasing attitudes to foods enriched with omega-3 fatty acids in the marketplace.

In a question, willingness to purchase listed foods enriched with omega-3 fatty acids was established. The results are presented in Figure 5. Yoghurt enriched with omega-3 fatty acids was preferred by $17 \%$, cereal and cheese by $15 \%$, milk and bread by $14 \%$, chocolate by $12 \%$, and biscuits by $11 \%$ respondents.

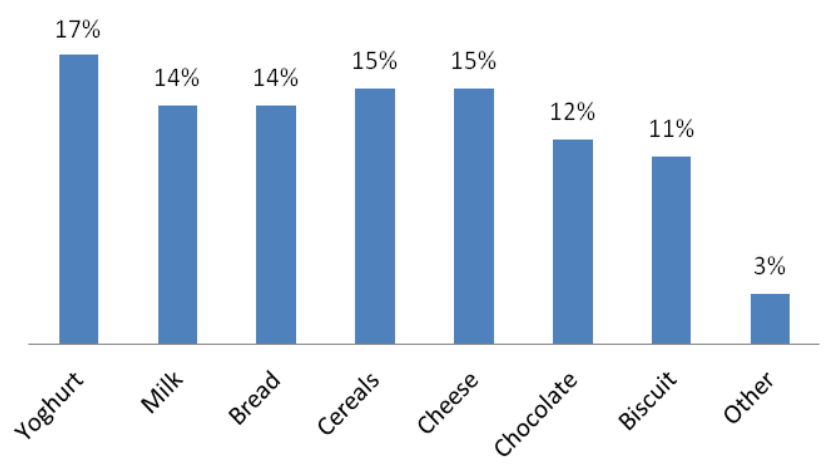

Figure 5. Distribution of participants according to buying preferences.

The factors affecting consumption levels and preferences of consumers were further investigated. Different situations were provided and respondents expected to evaluate the extent of consumption and preferences towards foods enriched with omega-3 fatty acids. According to the results (Figure 6), $43 \%$ participants readily consumed enriched products that were cheaper than normal products (statement 1) whereas $39 \%$ remained neutral in cases where enriched products were more expensive (statement 2). Moreover, $45 \%$ respondents were consumers of enriched products that were more nutritional than normal products (statement 3) and 38\% consumed enriched products with labels including health benefits (statement 4). In addition, $46 \%$ participants consumed enriched products with a similar taste to non-enriched counterpart products (statement 5). Overall, 50\% participants readily consumed enriched products recommended by their doctors (statement 6). Statistical analysis revealed no significant differences in consumption preferences based on gender $(P>0.05)$. On the other hand, marital status was associated with significant differences for statements $2(P=0.01)$, $4(P=0.02)$ and $6(P=0.025)$. The $18-30$ and $41-50$ year age groups showed significant differences $(P<0.05)$, except in the case of statement $1(P>0.05)$. Moreover, among the education level categories examined, high school and higher degree level groups showed significant differences for statements 1 $(P=0.036)$ and $4(P=0.014)$. Statements $2(P=0.001)$ and 5 $(P=0.038)$ were markedly different for specific income level groups (<1000 TRY and 2000-3000 TRY).

\subsubsection{Examining the relationship between categorical variables}

Comparisons about omega-3 containing food consumption frequency were made according to gender, age, education, income, occupation and marital status.

According to statistical analysis results (Table 2), a significant difference between flaxseed, walnut, purslane consumption frequency and gender was observed $(\mathrm{p}<0.05)$. Moreover, significant difference was also observed between fish, flaxseed, walnut, purslane, soybean oil consumption frequency and age $(p<0.05)$. Fish consumption frequency was related with education and income levels $(\mathrm{p}<0.05)$. There was a statistically significant difference between fish, purslane, soybean oil and occupation $(p<0.05)$, whereas significant difference was observed between fish, walnut, purslane and marital status $(\mathrm{p}<0.05)$. 


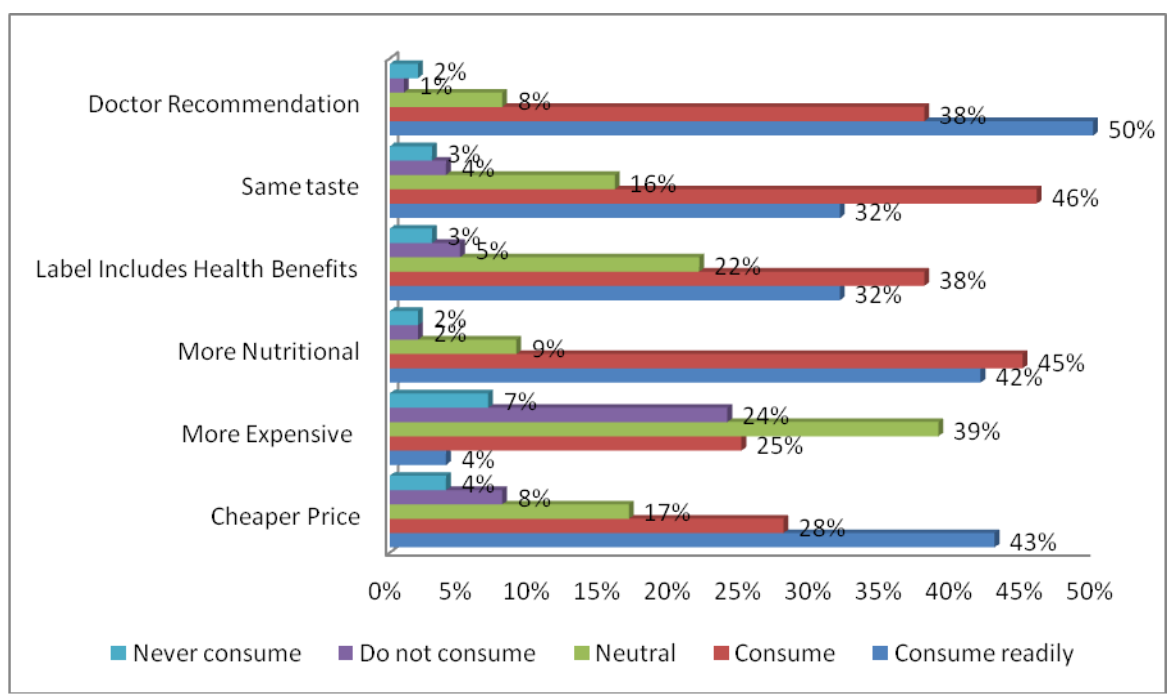

Figure 6. Distribution of participants according to situations affecting buying decisions.

\subsubsection{Reliable Information Source}

In the last question of the survey, participants were asked about the three most reliable sources of information on foods enriched with omega-3 fatty acids. Overall, doctors (29\%), universities/research institutions $(29 \%)$ and non-governmental organizations $(19 \%)$ were considered the three most reliable information sources while $6 \%$ participants found media reliable. In addition, $15 \%$ respondents found official institutions reliable.

\subsection{Discussion}

Development and marketing of new functional food products are partly depending on the acceptance of consumers (Siró et al., 2008). Unfortunately, there is a lack of consumer studies relating to omega-3 enriched foods in Turkey. This study will fill the research gap in order to reveal the omega-3 fatty acid consumption patterns, consumer attitudes, and preferences towards functional foods enriched with omega-3 fatty acids.

Diets including omega-3 fatty acids have a crucial role for human health and diseases. Consumer knowledge is a significant factor to benefit from these dietary lipids' health effects and to contribute public health. Additionally, from a marketing perspective, it is important to know what extent the consumers' knowledge about omega-3 fatty acids. According to current survey results, nearly all the participants (98\%) knew the term "omega-3 fatty acids". Data gathered from the consumer survey studies conducted in Turkey unraveled that different information sources such as internet, television, newspapers may contribute to increase society's knowledge level of functional foods. In this study, among the given alternative information sources, television had the highest score (43\%). Similarly, Gezginç and Gök (2016) found that most of the participants learned the functional foods concept from television (47\%), whereas internet was the most selected information source $(25 \%)$ according to another consumer survey about functional foods (Öncebe \& Demircan, 2019).

Fishes, especially marine fishes supply more omega-3 fatty acids (EPA and DHA) (Williams \& Burdge, 2006). In the survey, fish had the highest consumption frequency among the given specific foods containing omega-3 fatty acids. $33 \%$ of the respondents stated that they consumed fish once a week and $11 \%$ participants consumed fish less than once a month (the lowest frequency of fish consumption). Our data are consistent with an earlier survey conducted in Istanbul by Erdoğan et al. (2011) which showed that nearly $35 \%$ participants consumed seafood once a week and $\sim 5 \%$ consumed seafood less than once a month.

Supplementation of n-3 PUFA in feed formulations resulted with increased growth performance and environmental effects. This is considered to be an obvious potential application for intensive hatcheries (Y1lmaz, 2020).

Consumers' needs and preferences must be taken into account in food industry especially during the development of new food products (Moors \& Donders, 2009). Our study showed that the majority of participants $(72 \%)$ preferred to consume omega-3 fatty acids from their own sources while only $11 \%$ preferred omega- 3 enriched foods. The respondents in the survey purchased predominantly margarine $(33 \%)$, vegetable oil $(27 \%)$ and eggs $(25 \%)$ as functional foods enriched with omega-3 fatty acids. Likewise, Öncebe and Demircan (2019) conducted a consumer survey on 384 participants in Isparta, Turkey, to investigate the factors affecting consumer behavior towards functional foods. According to the responses, $\sim 15 \%$ consumers purchased eggs enriched with omega-3 fatty acids. Another survey performed in Adana, Turkey, revealed that omega-3 enriched fats and oils were consumed by $60 \%$ of the participants (Gezginç \& Gök, 2016). Moreover, according to a survey with 306 academic correspondents in İzmir, Turkey, it was observed that, $38 \%$ consumed omega-3/selenium enriched eggs, $42 \%$ knew about the product but did not use it and $20 \%$ did not know about the product (Hacioğlu \& Kurt, 2012). In contrast, another consumer survey $(n=222)$ from Greece has revealed that only 2 participants consumed omega-3 enriched eggs, while 7 participants recognized but have not tested omega-3 eggs and omega-3 enriched milk (Karelakis et al., 2020). Furthermore, according to the results of an online survey $(n=307)$ conducted in Brazil, the consumers had positive attitude towards frankfurters enriched with omega-3 fatty acids (Polizer Rocha et al., 2019).

Consumer knowledge and awareness are closely related to buying behavior according to results of our study. Margarine, vegetable oil and eggs had higher scores among the listed foods declared or labeled as "containing omega-3 fatty acids" in the survey. 
Table 2. Comparison of omega-3 containing food consumption frequency according to age $(n=819)$

\begin{tabular}{|c|c|c|c|c|c|c|c|c|c|c|}
\hline & & \multicolumn{2}{|c|}{$18-30$} & \multicolumn{2}{|c|}{$21-40$} & \multicolumn{2}{|c|}{$41-50$} & \multicolumn{2}{|c|}{$>51$} & \multirow[b]{2}{*}{ p } \\
\hline & $\begin{array}{c}\text { Frequency } \\
\qquad *\end{array}$ & $\mathbf{N}$ & $\%$ & $\mathbf{N}$ & $\%$ & $\mathbf{N}$ & $\%$ & $\mathbf{N}$ & $\%$ & \\
\hline \multirow{5}{*}{$\frac{2}{5}$} & 1. & 51 & $10.3 \%$ & 20 & $13.2 \%$ & 28 & $27.7 \%$ & 9 & $17.3 \%$ & \multirow[t]{5}{*}{$<0.001$} \\
\hline & 2. & 133 & $26.8 \%$ & 71 & $46.7 \%$ & 39 & $38.6 \%$ & 18 & $34.6 \%$ & \\
\hline & 3. & 117 & $23.6 \%$ & 28 & $18.4 \%$ & 16 & $15.8 \%$ & 9 & $17.3 \%$ & \\
\hline & 4. & 120 & $24.2 \%$ & 23 & $15.1 \%$ & 14 & $13.9 \%$ & 13 & $25.0 \%$ & \\
\hline & 5. & 75 & $15.1 \%$ & 10 & $6.6 \%$ & 4 & $4.0 \%$ & 3 & $5.8 \%$ & \\
\hline \multirow{5}{*}{ 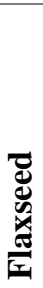 } & 1. & 12 & $2.9 \%$ & 4 & $4.0 \%$ & 5 & $8.6 \%$ & 4 & $13.3 \%$ & \multirow[t]{5}{*}{0.045} \\
\hline & 2. & 18 & $4.3 \%$ & 2 & $2.0 \%$ & 3 & $5.2 \%$ & 3 & $10.0 \%$ & \\
\hline & 3. & 17 & $4.1 \%$ & 4 & $4.0 \%$ & 0 & $0.0 \%$ & 0 & $0.0 \%$ & \\
\hline & 4. & 27 & $6.5 \%$ & 9 & $8.9 \%$ & 5 & $8.6 \%$ & 4 & $13.3 \%$ & \\
\hline & 5. & 342 & $82.2 \%$ & 82 & $81.2 \%$ & 45 & $77.6 \%$ & 19 & $63.3 \%$ & \\
\hline \multirow{5}{*}{$\frac{\Xi}{\vec{E}}$} & 1. & 161 & $33.6 \%$ & 69 & $47.9 \%$ & 62 & $64.6 \%$ & 33 & $67.3 \%$ & \multirow[t]{5}{*}{$<0.001$} \\
\hline & 2. & 85 & $17.7 \%$ & 24 & $16.7 \%$ & 11 & $11.5 \%$ & 4 & $8.2 \%$ & \\
\hline & 3. & 76 & $15.9 \%$ & 17 & $11.8 \%$ & 13 & $13.5 \%$ & 2 & $4.1 \%$ & \\
\hline & 4. & 90 & $18.8 \%$ & 15 & $10.4 \%$ & 5 & $5.2 \%$ & 5 & $10.2 \%$ & \\
\hline & 5. & 67 & $14.0 \%$ & 19 & $13.2 \%$ & 5 & $5.2 \%$ & 5 & $10.2 \%$ & \\
\hline \multirow{5}{*}{ 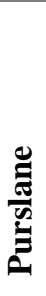 } & 1. & 26 & $6.0 \%$ & 8 & $6.6 \%$ & 4 & $5.0 \%$ & 6 & $13.0 \%$ & \multirow[t]{5}{*}{0.004} \\
\hline & 2. & 29 & $6.7 \%$ & 16 & $13.1 \%$ & 12 & $15.0 \%$ & 7 & $15.2 \%$ & \\
\hline & 3. & 61 & $14.0 \%$ & 13 & $10.7 \%$ & 22 & $27.5 \%$ & 7 & $15.2 \%$ & \\
\hline & 4. & 122 & $28.0 \%$ & 35 & $28.7 \%$ & 18 & $22.5 \%$ & 10 & $21.7 \%$ & \\
\hline & 5. & 197 & $45.3 \%$ & 50 & $41.0 \%$ & 24 & $30.0 \%$ & 16 & $34.8 \%$ & \\
\hline \multirow{5}{*}{ 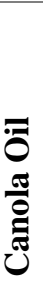 } & 1. & 4 & $1.0 \%$ & 1 & $1.0 \%$ & 0 & $0.0 \%$ & 2 & $8.0 \%$ & \multirow[t]{5}{*}{0.183} \\
\hline & 2. & 6 & $1.5 \%$ & 1 & $1.0 \%$ & 0 & $0.0 \%$ & 0 & $0.0 \%$ & \\
\hline & 3. & 9 & $2.2 \%$ & 0 & $0.0 \%$ & 2 & $4.7 \%$ & 0 & $0.0 \%$ & \\
\hline & 4. & 18 & $4.5 \%$ & 5 & $4.9 \%$ & 1 & $2.3 \%$ & 1 & $4.0 \%$ & \\
\hline & 5. & 367 & $90.8 \%$ & 95 & $93.1 \%$ & 40 & $93.0 \%$ & 22 & $88.0 \%$ & \\
\hline \multirow{5}{*}{ 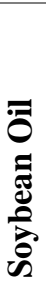 } & 1. & 4 & $1.0 \%$ & 0 & $0.0 \%$ & 0 & $0.0 \%$ & 2 & $8.0 \%$ & \multirow[t]{5}{*}{0.040} \\
\hline & 2. & 13 & $3.2 \%$ & 3 & $3.0 \%$ & 1 & $2.4 \%$ & 0 & $0.0 \%$ & \\
\hline & 3. & 13 & $3.2 \%$ & 0 & $0.0 \%$ & 1 & $2.4 \%$ & 1 & $4.0 \%$ & \\
\hline & 4. & 29 & $7.1 \%$ & 2 & $2.0 \%$ & 2 & $4.9 \%$ & 2 & $8.0 \%$ & \\
\hline & 5. & 348 & $85.5 \%$ & 94 & $94.9 \%$ & 37 & $90.2 \%$ & 20 & $80.0 \%$ & \\
\hline \multirow{5}{*}{ 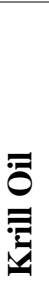 } & 1. & 2 & $0.5 \%$ & 1 & $1.0 \%$ & 0 & $0.0 \%$ & 2 & $8.7 \%$ & \multirow[t]{5}{*}{0.072} \\
\hline & 2. & 1 & $0.2 \%$ & 0 & $0.0 \%$ & 0 & $0.0 \%$ & 0 & $0.0 \%$ & \\
\hline & 3. & 6 & $1.5 \%$ & 1 & $1.0 \%$ & 1 & $2.4 \%$ & 0 & $0.0 \%$ & \\
\hline & 4. & 9 & $2.2 \%$ & 2 & $2.0 \%$ & 0 & $0.0 \%$ & 1 & $4.3 \%$ & \\
\hline & 5. & 386 & $95.5 \%$ & 94 & $95.9 \%$ & 40 & $97.6 \%$ & 20 & $87.0 \%$ & \\
\hline
\end{tabular}

*1: Two or more times per week; 2: Once a week ; 3: two to one; 4: once a month ; 5: Less 
In addition, the participants mostly preferred buying these three omega-3 enriched food items. Additionally, market potential of functional cookies containing flaxseed that is rich in omega-3 fatty acids were investigated via an online questionnaire $(n=1035)$ in Croatian by Cukelj et al. (2016). It was found that the consumers with higher nutrition knowledge and consciousness were more interested in the functional cookies with omega-3 fatty acids. So, increased consumer awareness and knowledge towards omega-3 enriched foods may provide a variety of successful new functional foods (Moors \& Donders, 2009).

Price and health effects are important factors influencing willingness to buy (Urala \& Lähteenmäki, 2007). Most of the participants stated that they consume readily enriched products when they have some health benefits and have higher nutrition values or are cheaper than normal products. Besides, doctor recommendation affected purchase intent of half of the participants. Our findings are parallel to the consumer studies conducted in Turkey by Sevilmiş et al. (2017) and Öncebe and Demircan (2019) as the results of the surveys indicated that the participants preferred to purchase functional food products having beneficial health effects.

In the current study, $58 \%$ of the respondents declared that the most reliable information sources were doctors and universities/research institutions. Based on these results, public service announcements can be created within the framework of the cooperation of universities, research institutes, producers and government in order to increase consumer knowledge and to improve public health.

\section{Conclusions and Recommendations}

Here, we evaluated consumer knowledge, attitudes and preferences with regard to omega-3 fatty acids and omega-3 enriched foods in Istanbul via a consumer survey. Among the 819 participants, only $2 \%$ had no prior knowledge of omega- 3 fatty acids whereas $43 \%$ had been made aware of the term on television for the first time. Moreover, $43 \%$ participants had encountered foods enriched with omega-3 fatty acids. Overall, $72 \%$ participants consumed omega- 3 fatty acids from natural sources, $17 \%$ consumed fish oil capsules, and only $11 \%$ preferred foods enriched with omega- 3 fatty acids. In addition, participants preferred enriched foods with more nutritional value, labels with health benefits, and similar taste to nonenriched foods.

In addition, fish consumption frequency was found to be related with education and income levels. Therefore, it can be a solution to the insufficient intake of the society by adding omega-3 fatty acids to the foods widely consumed by the Turkish society.

Blood levels of EPA+DHA are variable across the globe, with most of the countries and regions of the world having levels that are considered low to very low (Stark et al., 2016; Stanton et. al, 2020). Very low bloods levels observed for Turkey might associate with an increased risk in cardiovascular related mortality. Therefore, efforts are needed to increase the consumption of omega-3 fatty acids either by natural sources/supplements or foods enriched with omega-3 fatty acids (Stanton et. al, 2020).
This study was conducted to evaluate consumer attitudes and preferences regarding omega-3 enriched functional foods, since consumer studies are limited in this field. Further up to date studies with increased sample sizes are essential for improving understanding of consumer attitudes, awareness and preferences towards omega- 3 fatty acid-enriched functional foods.

\section{References}

Cox, D.N., Evans, G., \& Lease, H.J. (2008). Australian consumers' preferences for conventional and novel sources of long chain omega-3 fatty acids: A conjoint study. Food Quality and Preference, 19(3), 306-314. https://doi.org/10.1016/j.foodqual.2007.10.006

Cukelj, N., Putnik, P., Novotni, D., Ajredini, S., Voucko, B., \& Curic, D. (2016). Market potential of lignans and omega-3 functional cookies. British Food Journal, 118(10), 2420 2433. https://doi.org/10.1108/BFJ-03-2016-0117

Erdoğan, B.E., Mol, S., \& Coşansu, S. (2011). Factors influencing the consumption of seafood in Istanbul, Turkey. Turkish Journal of Fisheries and Aquatic Sciences, 11, 631639. https://doi.org/10.4194/1303-2712-v11_4_18

Gezginç, Y., \& Gök, S. (2016). Adana ili örneği ile tüketicilerin fonksiyonel gidalara yönelik farkındalığı. Atatürk Üniversitesi Ziraat Fakültesi Dergisi, 47(2), 101-106.

Hacioğlu, G., \& Kurt, G. (2012). Tüketicilerin fonksiyonel gıdalara yönelik farkındalığı, kabulü ve tutumları: İzmir ili örneği. Business and Economics Research Journal, 3(1), 161-171.

Jacobsen, C. (2010). Enrichment of foods with omega-3 fatty acids: a multidisciplinary challenge. Annals of the New York Academy of Sciences, 1190(1), 141-150. https://doi.org/10.1111/j.1749-6632.2009.05263.x

Karelakis, C., Zevgitis, P., Galanopoulos, K., \& Mattas, K. (2020). Consumer trends and attitudes to functional foods, Journal of International Food \& Agribusiness Marketing, 32(3), 266-294. https://doi.org/10.1080/08974438.2019.1599760

Lane, K.E., \&Derbyshire, E.J. (2018). Omega-3 fatty acids - A review of existing and innovative delivery methods. Critical Reviews in Food Science and Nutrition, 58(1), 62-69. https://doi.org/ 10.1080/10408398.2014.994699

Mazza, M., Pomponi, M., Janiri, L., Bria, P., \& Mazza, S. (2007). Omega-3 fatty acids and antioxidants in neurological and psychiatric diseases: an overview. Progress in Neuro-Psychopharmacolgy and Biological Psychiatry, 31(1), 12-26. https://doi.org/10.1016/j.pnpbp.2006.07.010

Moors, H.M.E., \& Donders, R. (2009). Understanding consumer needs and preferences in new product development: the case of functional food innovations. Innovation Studies Utrecht (ISU) working paper series 09-03, Utrecht University, Department of Innovation Studies, revised Feb 2009.

Öncebe, S., \& Demircan, V. (2019). Tüketicilerin fonksiyonel g1da tüketimini etkileyen faktörler. Akademik Gıda, 17(4), 497-507. https://doi.org/10.24323/akademik-gida.667263

Patch, C.S., Tapsell, L.C., \& Williams, P.G. (2005). Attitudes and intentions towards purchasing novel foods enriched with omega-3 fatty acids. Journal of Nutrition Education and Behavior, 37(5), 235-241. https://doi.org/10.1016/s14994046(06)60277-7 
Polizer Rocha, Y.J., de Noronha, R.L.F., \& Trindade, M.A. (2019). Relations between consumer's concern with own health and their perception about frankfurters with functional ingredients. Meat Science, 155, 91-101. https://doi.org/10.1016/j.meatsci.2019.05.003

Saini, R.K., \& Keum, Y-S. (2018). Omega-3 and omega-6 polyunsaturated fatty acids: Dietary sources, metabolism, and significance - a review. Life Sciences, 203, 255-267. https://doi.org/10.1016/j.lfs.2018.04.049

Sevilmiş, G., Olgun, A., \& Artukoğlu, M. (2017). Fonksiyonel gıdalarda tüketici kararlarını etkileyen faktörler üzerine bir araştırma: İzmir İli örneği. Ege Üniversitesi Ziraat Fakültesi Dergisi, 54(3), 351-360. https://doi.org/10.20289/zfdergi.388102

Siró, I., Kápolna, E., Kápolna, B., \& Lugasi, A. (2008). Functional food product development, marketing and consumer acceptance - a review. Appetite, 51(3), 456-467. https://doi.org/10.1016/j.appet.2008.05.060

Stanton, A.V., James, K., Brennan, M. M., O'Donovan, F., Buskandar, F., Shortall, K., El-Sayed, T., Kennedy, J., Hayes, H., Fahey, A. G., Pender, N., Thom, S.A.M., Moran, N., Williams DJ, \& Dolan, E. (2020). Omega-3 index and blood pressure responses to eating foods naturally enriched with omega-3 polyunsaturated fatty acids: a randomized controlled trial. Scientific Reports, 10(1):15444. https://doi.org/10.1038/s41598-020-71801-5.

Stark, K.D., Van Elswyk, M.E., Higgins, R., Weatherford, C.A., Salem, N. (2016). Global survey of the omega-3 fatty acids, docosahexaenoic acid and eicosapentaenoic acid in the blood stream of healthy adults Ken D. Stark a, Progress in Lipid Research. 63 (2016) 132-152. https://doi.org/10.1016/j.plipres.2016.05.001.

Swanson, D., Block, R., \& Mousa, S.A. (2012). Omega-3 fatty acids EPA and DHA: Health benefits throughout life. Advances in Nutrition, 3(1), 1-7. https://doi.org/ 10.3945/an.111.000893

T.C. Sağlık Bakanlığı, Türkiye Beslenme ve Sağlık Araştırması (TBSA), (2019), Tiraj Basım ve Yayın San. Tic. Ltd. Şti., Çankaya, ANKARA.

Urala, N., \& Lähteenmäki, L. (2007). Consumers changing attitudes towards functional foods. Food Quality and Preference, $18(1)$, 1-12. https://doi.org/10.1016/j.foodqual.2005.06.007

Williams, C.M., \& Burdge, G. (2006). Long-chain n-3 PUFA: plant vs. marine sources. Proceedings of the Nutrition Society, 65(1), 42-50. https://doi.org/ 10.1079/pns2005473

Yılmaz, A.H. (2020). N-3 HUFA'ca zenginleştirilmiş Artemia ile beslenen Yeşil kaplan karidesi (Penaeus semisulcatus) larvalarının büyüme performansı, Avrupa Bilim ve Teknoloji Dergisi, 20, 30-34.

https://doi.org/10.31590/ejosat.776363 